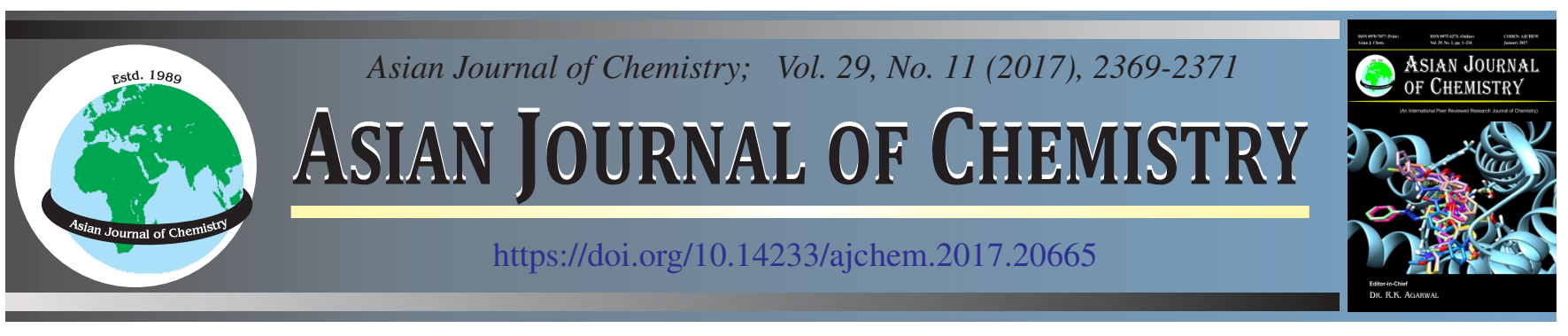

\title{
Synthesis and Antimicrobial Studies of 5-N-alkyl-1,3,4-oxadiazole-2-thiol Derivatives from Fatty Acids
}

B. Naga Sudha*, N. Yella Subbaiah, A.M. Srikanth, C. Venkata Ramana Reddy, M. Sneha Latha and P. Vijaya Lakshmi

Department of Pharmaceutical Chemistry, C.E.S. College of Pharmacy, Kurnool-518 218, India

*Corresponding author: E-mail: sudulumpharm@yahoo.com

Received: 22 March 2017;

Accepted: 15 June 2017;

Published online: 29 September 2017;

AJC-18552

\begin{abstract}
The novel 5-N-alkyl-1,3,4-oxadiazole-2-thiol derivatives have been synthesized by esterification of fatty acid followed by reaction the ester with hydrazine hydrate. The acid hydrazide was converted to 1,3,4-oxadiazole by ring closure mechanism. The synthesized compounds have been characterized by physical (melting point and TLC) and spectral (IR, ${ }^{1} \mathrm{H}$ NMR and mass) data. All the compounds were screened for their antimicrobial activity. The compounds $\mathbf{3 F}_{\mathbf{1}} \& \mathbf{3 F}_{\mathbf{4}}$ showed good inhibition activity against all four types of bacteria; while compound $\mathbf{3} \mathbf{F}_{2} \& \mathbf{3 F}_{3}$ shown moderate activity.
\end{abstract}

Keywords: 1,3,4-Oxadiazole, Fatty acids, Acid hydrazides, Anti-microbial activity.

\section{INTRODUCTION}

The macronutrient groups are dietary fats, lipids that include fatty acids, triglycerides, cholesterol, essential fatty acids, linoleic and $\alpha$-linoleic acid. Fats are a key factor for the maintenance caloric balance and to the body weight. Specific fatty acids are also serves as precursor for numerous biological functions. Fat soluble vitamins (i.e., vitamin A, D, E, K) and carotenoids are engaged in pathways that influence inflammation, coagulation and gene expression which are transported by fats [1].

1,3,4-Oxadiazole are an important class of heterocyclic compounds with a wide range of pharmaceutical and biological activity [2-4]. Their synthesis and transformations have been of interest for a long time. This interesting group of compounds possesses diverse biological activity such as antimicrobial $[5,6]$, anti-inflammatory [7], antitubercular [8], anticonvulsant [9], anti-cancer [10], anti-HIV [11], hypoglycemic [12] and genotoxic $[13,14]$ activities.

In view of above mentioned pharmacological importance of fatty acids and 1,3,4-oxadiazole our ongoing efforts to synthesize a novel derivatives of 5-N-alkyl-1,3,4-oxadiazole-2-thiol $\left(\mathbf{3} \mathbf{F}_{\mathbf{1}}-\mathbf{F}_{\mathbf{4}}\right)$ and evaluated them for their potential as antimicrobial agents.

\section{EXPERIMENTAL}

Melting point taken in open capillary tubes using Arson digital melting point apparatus and were uncorrected. IR spectra were recorded on BRUKER Alpha FTIR spectrometer,
${ }^{1} \mathrm{H}$ NMR spectra were recorded on BRUKER (400 MHz) in DMSO- $d_{6}$ using TMS as an internal standard. Mass spectra were recorded in apex mass spectrophotometer. The purity of the compounds for checked in silica gel-G precoated plates by using $n$-hexane and ethyl acetate $(1: 1)$ as the eluent and observed in UV-chamber.

Synthesis of acid esters $\left(\mathbf{1 F}_{\mathbf{1}}-\mathbf{1 F}_{\mathbf{4}}\right)$ : Fatty acid $(10 \mathrm{~g})$, in $35 \mathrm{~mL}$ of methanol and concentrated sulphuric acid was added through sides of the walls. The resulting mixture was allowed to reflux for $5 \mathrm{~h}$, the contents were allowed to cool on water bath. To this, $5 \%$ sodium bicarbonate was added and the resulting mixture was filtered and recrystalized from methanol.

Synthesis of acid hydrazide $\left(\mathbf{2} \mathbf{F}_{\mathbf{1}}-\mathbf{2} \mathbf{F}_{\mathbf{4}}\right)$ : Dissolved the esters of substituted fatty acids $(0.01 \mathrm{~mol})$, in $4 \mathrm{~mL}$ of hydrazine hydrate was added drop wise with stirring. The resulting mixture was allowed to reflux for $4 \mathrm{~h}$. The reaction mixture was cooled to room temperature and diluted with water. It was filtered, washed thoroughly with water. The product was purified by recrystallization from methanol.

Synthesis of 5-N-alkyl-1,3, 4-oxadiazole-2-thiol $\left(\mathbf{3 F}_{\mathbf{1}^{-}}\right.$ $\left.\mathbf{3 F}_{4}\right)$ : Potassium hydroxide $(0.01 \mathrm{~mol})$ was dissolved in absolute ethanol $(50 \mathrm{~mL})$. To the above solution, acid hydazide (2) and carbon disulfide $(0.01 \mathrm{~mol})$ was added. The reaction mixture was refluxed on water bath for $38 \mathrm{~h}$ until hydrogen sulphide ceased completely. The reaction mixture was cooled to room temperature. On acidification with dil. hydrochloric acid, the precipitate was obtained which was filtered, washed thoroughly with water and recrystallized from ethanol. 
5-(Heptadec-8-1-yl)-1,3,4-oxadiazole-2-thiol $\left(3 \mathrm{~F}_{1}\right)$ : Yield: $30 \%$; m.p.: $174-179{ }^{\circ} \mathrm{C}$; IR $\left(\mathrm{KBr}, \mathrm{v}_{\max }, \mathrm{cm}^{-1}\right): 2937$ (C-H stretching long alkyl chain), 1477 (C-O-C stretching), $1595(\mathrm{C}=\mathrm{C}$ stretching), $1716(\mathrm{C}=\mathrm{N}$ stretching $), 2384(\mathrm{C}-\mathrm{SH}$ stretching); ${ }^{1} \mathrm{H}$ NMR $\delta: 0.87-0.88$ (t, 3H, terminal $\left.\mathrm{CH}_{3}\right), 1.20$ 1.41 (m, 20H, - $\mathrm{CH}_{2^{-}}$), 1.45-1.48 (d, $2 \mathrm{H},-\mathrm{CH}_{2}-$ ), 1.94-1.97 (d, $4 \mathrm{H}$, allylic protons), 2.14-2.18 (t, $\left.2 \mathrm{H},-\mathrm{CH}_{2}-\right)$, 5.30-5.35 (d, $2 \mathrm{H}, \mathrm{CH}=\mathrm{CH}) ; \mathrm{MS} m / z: 340(\mathrm{M}+2)$.

5-Pentadecyl-1,3,4-oxadiazole-2-thiol $\left(\mathbf{3 F}_{2}\right)$ : Yield (\%): $45 \%$; m.p.: $174.17^{\circ} \mathrm{C}$; IR $\left(\mathrm{KBr}, v_{\max }, \mathrm{cm}^{-1}\right)$ : 2935 (C-H stretching, long alkyl chain), 1168 (C-O-C stretching), 1623 (C=N stretching), 1064 (C-O stretching), 2383 (C-SH stretching); ${ }^{1} \mathrm{H}$ NMR $\delta$ : $0.82-0.85\left(\mathrm{t}, 3 \mathrm{H}\right.$, terminal $\left.\mathrm{CH}_{3}\right), 1.22-1.25\left(\mathrm{~m}, 25 \mathrm{H},-\mathrm{CH}_{2}-\right), 1.57-$ $1.64\left(\mathrm{~m}, 2 \mathrm{H},-\mathrm{CH}_{2}-\right), 2.66-2.69$ (t, $\left.2 \mathrm{H},-\mathrm{CH}_{2}-\right), 14.25$ (s, $\left.1 \mathrm{H}, \mathrm{SH}\right)$; MS $m / z: 312\left(\mathrm{M}^{+}\right)$.

5-Heptadecyl-1,3,4-oxadaizole-2-thiol $\left(\mathbf{3 F}_{3}\right)$ : Yield (\%): $52 \%$; m.p.: 80-85 ${ }^{\circ} \mathrm{C}$; IR $\left(\mathrm{KBr}, v_{\max }, \mathrm{cm}^{-1}\right): 2935(\mathrm{C}-\mathrm{H}$ stretching), 1168 (C-O-C stretching), 1622 (C=N stretching), 1063 (C-O stretching), 2383 (C-SH, stretching); ${ }^{1} \mathrm{H}$ NMR $\delta: 0.85$ (t, 3H, terminal $\mathrm{CH}_{3}$ ), $1.22-1.25\left(\mathrm{~m}, 28 \mathrm{H},-\mathrm{CH}_{2}-\right.$ ), $1.57-1.64$ (m, $\left.2 \mathrm{H},-\mathrm{CH}_{2}-\right), 2.65-2.69\left(\mathrm{t}, 2 \mathrm{H},-\mathrm{CH}_{2}-\right), 14.25(\mathrm{~s}, 1 \mathrm{H}, \mathrm{SH}) ; \mathrm{MS}$ $m / z: 341\left(\mathrm{M}^{+1}\right)$.

5-Undecyl-1,3,4-oxadiazole-2-thiol (3F $\left.\mathbf{F}_{4}\right)$ :Yield (\%): $48 \%$; m.p.: 79-82 ${ }^{\circ} \mathrm{C}$; IR $\left(\mathrm{KBr}, v_{\max }, \mathrm{cm}^{-1}\right): 2936(\mathrm{C}-\mathrm{H}$ stretching), 1177 (C-O-C stretching), 1517 (C=N stretching), 1065 (C-O stretching), 2384 (C-SH stretching); ${ }^{1} \mathrm{H}$ NMR $\delta: 0.82-0.85$ (t, $3 \mathrm{H}$, terminal $\mathrm{CH}_{3}$ ), $1.15-1.26\left(\mathrm{~m}, 17 \mathrm{H},-\mathrm{CH}_{2}-\right), 1.57-1.64$ (m, $\left.2 \mathrm{H},-\mathrm{CH}_{2}-\right), 2.66-2.70\left(\mathrm{t}, 2 \mathrm{H},-\mathrm{CH}_{2^{-}}\right), 14.25(\mathrm{~s}, 1 \mathrm{H}, \mathrm{SH}) ; \mathrm{MS}$ $m / z: 256\left(\mathbf{M}^{+}\right)$.

Antimicrobial activity: The antimicrobial activity of title compounds determined in vitro by using disc diffusion method by using four types microorganisms like E. coli, P. aeruginosa (Gram-positive), S. aureus, B. subtilis (Gram-negative) at 50, $100 \mu \mathrm{g} \mathrm{mL}^{-1}$ concentrations respectively, in the nutrient agar media by measuring the zone of inhibition in $\mathrm{mm}$. The solution of required concentrations $\left(50,100 \mu \mathrm{gL}^{-1}\right)$ of test compounds were prepared by dissolving the compounds in DMSO. Streptomycin was used as standard.

\section{RESULTS AND DISCUSSION}

As depicted in Scheme-I, in addition to 1,3,4-oxadiazoles we have synthesized 5-N-alkyl-1,3,4-oxadiazole-2-thiol $\left(\mathbf{3 F}_{\mathbf{1}}-\mathbf{3 F}_{\mathbf{4}}\right)$ through a three step reaction and acid ester of fatty acid (1) has been synthesized from fatty acid and methanol in the presence of conc. $\mathrm{H}_{2} \mathrm{SO}_{4}$ by esterification. In step 2, the formed ester of fatty acid was hydrazinolyzed to give acid hydrazides (2), which later cyclize to form a title compounds i.e. 5-N-alkyl1,3,4-oxadiazole-2-thiol $\left(\mathbf{3 F}_{\mathbf{1}}-\mathbf{3 F}_{\mathbf{4}}\right)$ by reacting with $\mathrm{CS}_{2}$ and $\mathrm{KOH}$ in ethanol. This procedure afforded various 1,3,4-oxadiazoles in moderate yields. The infrared spectra of the substituted 5-Nalkyl-1,3,4-oxadiazole-2-thiol $\left(\mathbf{3 F}_{1}\right)$ showed characteristic absorption bands, one of the which appearing at $2936 \mathrm{~cm}^{-1}$ was strong alkyl chain $\mathrm{C}-\mathrm{H}$ which are all final compounds $\left(\mathbf{3 F}_{1}-\mathbf{3 F}_{4}\right)$ shown $1200-1100 \mathrm{~cm}^{-1} \mathrm{C}-\mathrm{O}-\mathrm{C}, 1600-1500 \mathrm{~cm}^{-1} \mathrm{C}=\mathrm{N}$ and $2354 \mathrm{~cm}^{-1}$ SH Group. Similarly, ${ }^{1} \mathrm{H}$ NMR spectra of synthesized compounds $\left(\mathbf{3 F}_{1}-\mathbf{3 F}_{4}\right)$ showed multiplet signals at $\delta 1.12-1.26 \mathrm{ppm}$ due to methylene protons. The terminal $\mathrm{CH}_{3}$ protons appeared as triplet at $\delta 0.82-0.85 \mathrm{ppm}$. The $\mathrm{SH}$ proton as a singlet at $\delta 14.22$ $\mathrm{ppm}$. A triplet at $\delta 5.30-5.35 \mathrm{ppm}$ integrating for 2 olefinic proton $(\mathrm{CH}=\mathrm{CH})$ was attributed to the $\mathrm{C}_{9}-\mathrm{C}_{10}$ proton of $\mathbf{3 F}_{1}$, doublet at 1.94-2.01 ppm for four allylic protons was attributed to $\mathrm{C}_{8}-\mathrm{C}_{11}$ protons of $\mathbf{3} \mathbf{F}_{1}$.

\begin{tabular}{|c|c|c|c|c|c|}
\hline \multicolumn{6}{|c|}{$\begin{array}{l}\text { TABLE-1 } \\
\text { ANTIMICROBIAL ACTIVITY OF 5-N-ALKYL-1,3,4-OXADIAZOLE-2-THIOL }\left(\mathbf{3 F}_{\mathbf{1}}-\mathbf{F}_{4}\right)\end{array}$} \\
\hline \multirow{3}{*}{ Compound code } & \multirow{3}{*}{ Conc. $(\mu \mathrm{g} / \mathrm{mL})$} & \multicolumn{4}{|c|}{ Zone of inhibition } \\
\hline & & \multicolumn{2}{|c|}{ Gram-positive organisms } & \multicolumn{2}{|c|}{ Gram-negative organisms } \\
\hline & & B. subtilis & S. aureus & E. coli & P. aeurignosa \\
\hline \multirow{2}{*}{$3 F_{1}$} & 50 & 20 & 10 & 24 & 12 \\
\hline & 100 & 25 & 15 & 27 & 18 \\
\hline \multirow{2}{*}{$3 F_{2}$} & 50 & 10 & 9 & 10 & $\mathrm{~N}$ \\
\hline & 100 & 17 & 14 & 12 & 9 \\
\hline \multirow{2}{*}{$3 F_{3}$} & 50 & $\mathrm{~N}$ & $\mathrm{~N}$ & 10 & $\mathrm{~N}$ \\
\hline & 100 & 9 & $\mathrm{~N}$ & 15 & 12 \\
\hline \multirow{2}{*}{$3 F_{4}$} & 50 & 22 & $\mathrm{~N}$ & 14 & $\mathrm{~N}$ \\
\hline & 100 & 27 & $\mathrm{~N}$ & 20 & 8 \\
\hline Streptomycin & 50 & 22 & 25 & 28 & 21 \\
\hline Control & & - & - & - & - \\
\hline
\end{tabular}



Scheme-I: Conventional synthetic route for 5-N-alkyl-1,3,4-oxadiazole-2-thiol 
The results of the antimicrobial study of the newly synthesized compounds was reported as zone of inhibition against E. coli, P. aeruginosa (Gram-positive), S. aureus, B. subtilis (Gram-negative) (Table-1). All the synthesized compounds have shown significant antimicrobial activity. The compound $\mathbf{3 F}_{\mathbf{1}}$ and $\mathbf{3 F}_{\mathbf{4}}$ showed maximum activity at both 50 and $100 \mu \mathrm{g} /$ $\mathrm{mL}$ concentrations whereas compounds $\mathbf{3} \mathbf{F}_{\mathbf{2}}$ and $\mathbf{3} \mathbf{F}_{\mathbf{3}}$ showed moderate activity. The results revealed that fatty acid moiety is a satisfactory backbone for significant antimicrobial activity and the presence of unsaturated double bonds in the structure of fatty acid is also responsible for the good activity. Thus by hybridization of 1,3,4-oxadiazole ring enhance the activity.

\section{Conclusion}

In this communication, our aim has been verified by the synthesis of 5-N-alkyl-1,3,4-oxadiazole-2-thiol $\left(\mathbf{3 F}_{\mathbf{1}} \mathbf{-}-\mathbf{3 F}_{\mathbf{4}}\right)$ derivatives in which 1,3,4-oxadiazole ring incorporated with fatty acid hydrazide moiety in a single frame work. Obtained results revealed that most of tested compounds showed promising activity as antimicrobial agents. After all the above findings it can be concluded that these molecule become lead molecule for further synthetic and biological evaluation.

\section{ACKNOWLEDGEMENTS}

The authors are thankful to IISc, Bangalore, SAIF IIT, Madras for the spectral analysis. The authors are also thankful to the CES College of Pharmacy, Kurnool, Andhra Pradesh, India for their help and support.

\section{REFERENCES}

1. W.C. Willet, W. Whang and J.E. Manson, Report of the DGAC on the Dietary Guidelines for Americans (2010).

2. P. Sengupta, M. Mal, S. Mandal, J. Singh and T.K. Maity, Iranian J. Pharmacol. Ther, 7, 165 (2008).

3. N. Bhardwaj, S.K. Saraf, P. Sharma and P. Kumar, E-J. Chem., 6, 1133 (2009); https://doi.org/10.1155/2009/698023.

4. A.A. Kadi, N.R. El-Brollosy, O.A. Al-Deeb, E.E. Habib, T.M. Ibrahim and A.A. El-Emam, Eur. J. Med. Chem., 42, 235 (2007); https://doi.org/10.1016/j.ejmech.2006.10.003.

5. L. Jin, J. Chen, B. Song, Z. Chen, S. Yang, Q. Li, D. Hu and R. Xu, Bioorg. Med. Chem. Lett., 16, 5036 (2006);

https://doi.org/10.1016/j.bmcl.2006.07.048.

6. N.K. Undavia, P.B. Trivedi, A.P. Shanishchara and V.P. Trivedi, J. Indian Chem. Soc., 82, 746 (2005).

7. S.G. Kucukguzel, I. Kucukguzel, E. Tatar, S. Rollas, F. Sahin, M. Güllüce, E. De Clercq and L. Kabasakal, Eur. J. Med. Chem., 42, 893 (2007); https://doi.org/10.1016/j.ejmech.2006.12.038.

8. G. Navarrete-Vazquez, G.M. Molina-Salinas, Z.V. Duarte-Fajardo, J. Vargas-Villarreal, S. Estrada-Soto, F. González-Salazar, E. HernándezNúñez and S. Said-Fernández, Bioorg. Med. Chem., 15, 5502 (2007); https://doi.org/10.1016/j.bmc.2007.05.053.

9. A. Zarghi, S.A. Tabatabai, M. Faizi, A. Ahadian, P. Navabi, V. Zanganeh and A. Shafiee, Bioorg. Med. Chem. Lett., 15, 1863 (2005); https://doi.org/10.1016/j.bmcl.2005.02.014.

10. S. Dash, B.A. Kumar, J. Singh, B.C. Maiti and T.K. Maity, Med. Chem. Res., 20, 1206 (2011);

https://doi.org/10.1007/s00044-010-9455-6.

11. H.P. Shah, B.R. Shah, J.J. Bhatt, N.C. Desai, P.B. Trivedi and N.K. Undavia, Indian J. Chem., 37B, 180 (1998).

12. E.D. Chrysina, M.N. Kosmopoulou, C. Tiraidis, R. Kardakaris, N. Bischler, D.D. Leonidas, Z. Hadady, L. Somsak, T. Docsa, P. Gergely, N.G. Oikonomakos, Protein Pharmacol., 14, 873 (2005); https://doi.org/10.1110/ps.041216105.

13. A.O. Maslat, M. Abussaud, H. Tashtoush and M. Al-Talib, Pol. J. Pharmacol., 54, 55 (2002). 